BJHS: Themes 2: 57-78, 2017. C British Society for the History of Science 2017. This is an Open Access article, distributed under the terms of the Creative Commons Attribution-NonCommercialShareAlike licence (http://creativecommons.org/licenses/by-nc-sa/4.0/), which permits noncommercial re-use, distribution, and reproduction in any medium, provided the same Creative Commons licence is included and the original work is properly cited. The written permission of Cambridge University Press must be obtained for commercial re-use.

doi:10.1017/bjt.2017.1 First published online 27 February 2017

\title{
The great cat mutilation: sex, social movements and the utilitarian calculus in 1970s New York City
}

\author{
MICHAEL PETTIT*
}

\begin{abstract}
In 1976, the animal liberation movement made experiments conducted on cats at the American Museum of Natural History (AMNH) one of its earliest successful targets. Although the scientific consensus was that Aronson was not particularly cruel or abusive, the AMNH was selected due to the visibility of the institution, the pet-like status of the animals, and the seeming perversity of studying non-human sexuality. I contextualize the controversy in terms of the changing meaning of utilitarian ethics in justifying animal experimentation. The redefinition of 'surgeries' as 'mutilations' reflected an encounter between the behavioural sciences and social movements. One of the aims of the late 1960s civil rights movements was to heighten Americans' sensitivity to differing experiences of suffering. The AMNH protesters drew inspiration from a revived utilitarian ethics of universal organismic pain across the lines of species. This episode was also emblematic of the emergence of an anti-statist, neo-liberal ethos in science. Invoking the rhetoric of the $1970 \mathrm{~s}$ tax revolt, animal liberationists attacked Aronson's ability to conduct basic research with no immediate biomedical application. Without denying the violence involved, an exclusive focus on reading the experiments through the lens of utilitarianism obscures what ethics animated Aronson's research.
\end{abstract}

The new social movements of the final third of the twentieth century posed a number of challenges to scientific authority. These movements questioned long-standing assumptions and privileges in numerous disciplines, altering research practices mediating between knower and scientific object. ${ }^{1}$ One of the most significant ways in which these movements transformed scientific practice has been in the realm of research ethics, especially around the contentious question of who ought to serve as a research subject. Revelations about the racial economy of the Tuskegee syphilis experiment brought the question of consent to the forefront of the emerging field of bioethics. ${ }^{2}$

\footnotetext{
* Faculty of Health, York University, 4700 Keele Street, Toronto, ON M3J 1P3, Canada. Email: mpettit@ yorku.ca.

1 Alexandra Rutherford, 'The social control of behavior control: behavior modification, individual rights, and research ethics in America, 1971-1979', Journal of the History of the Behavioral Sciences (2006) 42, pp. 203-220; Laura Stark, 'The science of ethics: deception, the resilient self, and the APA Code of Ethics, 1966-1973', Journal of the History of the Behavioral Sciences (2010) 46, pp. 337-370.

2 Susan Reverby, Examining Tuskegee: The Infamous Syphilis Study and Its Legacy, Chapel Hill: University of North Carolina Press, 2009.
} 
Feminists both questioned the easy translation of experimental data across the lines of sex and uncovered the risks that medical technologies posed to women's health. ${ }^{3}$ One area where this change has been most dramatic has been in the experimental use of non-human animals. How does the 1970s revival of animal welfare advocacy dovetail with existing narratives about the historical calculus over what kind of bodies should suffer for knowledge? ${ }^{4}$ In 1976, the emergent animal liberation movement successfully mobilized against research conducted at New York City's American Museum of Natural History $(\mathrm{AMNH})$ dealing with the sexual behaviour of cats. Activists redefined the work of psychologist Lester Aronson and his assistant Madeline Cooper as the perverted and wasteful mutilations of beloved household pets. The cat experiments became an acute matter of public concern as the scientists acquired an audience they neither anticipated nor desired. ${ }^{5}$

The details of the 1976 campaign are well known in the history of experimental ethics. Inspired by the philosopher Peter Singer's lectures on animal rights, activist Henry Spira used the recently passed Freedom of Information Act (FOIA) to acquire all the documents relating to Aronson's National Institutes of Health (NIH) grants going back to 1961. Spira used this information to rally public opinion against the cat experiments through a combination of exposé journalism, letter-writing campaigns and demonstrations outside the museum. He targeted research on cute 'companion animals' - taxfunded experiments at a highly visible institution that did not seem to have an immediate impact on human health. In the wake of the controversy, Aronson did not seek to renew his grant, and retired, and his Department of Animal Behavior (which had a longtroubled institutional history within the museum) was soon dissolved. It was heralded as the first political victory for the new animal liberation movement. ${ }^{6}$ Success is typically attributed to Spira's acumen as an inspired yet pragmatic organizer. Rather than seeking the unconditional abolition of all animal experiments, he brought before the public the utilitarian question 'How much pain for how much gain?'7 These narratives describe Aronson as too stubborn to change, a man whose career needed destroying for the

3 Steven Epstein, Inclusion: The Politics of Difference in Medical Research, Chicago: The University of Chicago Press, 2007; Wendy Kline, Bodies of Knowledge: Sexuality, Reproduction, and Women's Health in the Second Wave, Chicago: The University of Chicago Press, 2010; Michelle Murphy, Seizing the Means of Reproduction: Entanglements of Feminism, Health, and Technoscience, Durham, NC: Duke University Press, 2012.

4 Rebecca Herzig, Suffering for Science: Reason and Sacrifice in Modern America, New Brunswick, NJ: Rutgers University Press, 2005.

5 On the role of controversies in crafting publics see Noortje Marres, 'The issues deserve more credit: pragmatist contributions to the study of public involvement in controversy', Social Studies of Science (2007) 37, pp. 759-780.

6 The most detailed account is Peter Singer, Ethics into Action: Henry Spira and the Animal Rights Movement, Lanham, MD: Rowman \& Littlefield, 1998, pp. 55-74. See also Michael Allen Fox, The Case for Animal Experimentation: An Evolutionary and Ethical Perspective, Berkeley: University of California Press, 1986, pp. 107-110; James M. Jasper and Dorothy Nelkin, The Animal Rights Crusade: The Growth of a Moral Protest, New York: Free Press, 1992; Deborah Rudacille, The Scalpel and the Butterfly: The Conflict between Animal Research and Animal Protection, Berkeley: University of California Press, 2000, pp. 129-133.

7 Singer, op. cit. (6), p. 56. 
moral salvation of the next generation of scientists. Left unexamined is Aronson's tenacity in defending his research and the question whether he could have cared for the cats despite the violence that structured their relationship.

This essay seeks to elucidate why psychological research on the sexual behaviour of cats in New York City made for such a successful target. Spira conceded that the AMNH experiments affected only small numbers of animals compared with industrial uses from cosmetics testing to factory farming. ${ }^{8}$ Earlier accounts of the controversy neglect how shifts in both the moral and political economy for judging good science facilitated a new calculus for determining the value of non-human life. In important respects, Aronson exemplified the ideal of disinterested research characteristic of Cold War science. He departed most from the norms of mid-century behavioural science in his focus on studying the psychobiological development of animal individuality. He shared this commitment to the value of individual animal life with his opponents, although neither side acknowledged this common ground. Examining how science-policy analysts drew lessons from Spira's victory reveals important shifts from Cold War norms of scientific autonomy to greater emphasis on utility and immediate impact. In this new moral realm, Aronson's long-standing scientific practice was reinterpreted as wasteful violence.

Understanding violence against cats played a central role in my own formation as a historian. Robert Darnton's The Great Cat Massacre exemplifies the post-1960s moment when the primary task of the historian (and interpretive social scientist) was to relate the experience and agency of ordinary persons. Darnton calls upon the reader to enter into the world of the 1730 s print shop and to understand Nicolas Contat's violence and the humour he derived from it as a form of pre-Revolutionary political action. ${ }^{9}$ As historian Walter Johnson has argued, to give the subaltern 'back their agency' was a political move in the aftermath of the civil rights movement: a gesture to bestow humanity and hence human rights upon those who had so often been denied such dignities in the past. ${ }^{10}$ However, by the $1980 \mathrm{~s}$, the humanism of such moves was challenged by a host of 'new materialists' (e.g. Bruno Latour and Donna Haraway) who sought to demonstrate that things (e.g. apes, microbes, doorstoppers) also possessed agency. ${ }^{11}$ What I call the great cat mutilation offers a partial genealogy for how the paradoxical notion of 'non-human agency' became thinkable. The predominant narrative of interspecies relations focuses on a growing humanitarian sensibility. However, the late modern confrontation between animal rights activists and scientists underscores the uneven distribution of such care. The increased leisure and affect bestowed on household pets occurred alongside the intensified consumption of animals in science and agriculture. ${ }^{12}$

8 Henry Spira, 'Fighting to win', in Peter Singer (ed.), In Defense of Animals, New York: Basil Blackwell, 1985, pp. 194-208.

9 Robert Darnton, The Great Cat Massacre and Other Episodes in French Cultural History, New York: Basic Books, 1984, pp. 75-106.

10 Walter Johnson, 'On agency', Journal of Social History (2003) 37, pp. 113-124.

11 Edwin Sayes, 'Actor-network theory and methodology: just what does it mean to say that nonhumans have agency?', Social Studies of Science (2014) 44, pp. 134-149.

12 Julie Livingston and Jasbir K. Puar, 'Interspecies', Social Text (2011) 29, pp. 3-14. 
The notion of 'non-human agency' had a historical itinerary travelling through a new political calculus for suffering, the late modern metropolis's interspecies relations, and changes to the political economy of science following the collapse of the Cold War bubble. ${ }^{13}$ Opposition to Aronson's experiments benefited both from a heightened sensitivity about the abuse of human rights and civil liberties, and from an anti-statist critique of wasteful public spending leading to an attack on disinterested science. Ironically, the efforts of the animal liberationists unintentionally facilitated the emergence of the neoliberal regime for governing and evaluating science. ${ }^{14}$ At the same time, I hope that tracing this history demonstrates how the concept of 'non-human agency' remains haunted by often unacknowledged New Left and neo-liberal sensibilities.

\section{Sharing the burdens of medical progress}

Aronson never understood his opponents' ideology. ${ }^{15}$ Aronson's peers insisted that he was not particularly cruel or abusive towards his animals. His opponents concurred. They targeted him precisely because he seemed to exemplify the scientific consensus. ${ }^{16}$ Scientists of his generation had not been seriously challenged by animal welfare activists as the movement had been organizationally weak between the 1920s and 1960s. ${ }^{17}$ Indeed, the museum personnel dismissed the animal liberationists as an irrational relic of the Victorian age. ${ }^{18}$

The protection of animals, including opposition to their use in medical experiments, had been a prominent concern among nineteenth-century reformers. ${ }^{19}$ These anticruelty campaigners claimed that certain dependent entities (namely children and

13 On the shifts in the economy and culture of science $c .1970$ see Steven Shapin, The Scientific Life: A Moral History of a Late Modern Vocation, Chicago: The University of Chicago Press, 2008.

14 Neo-liberal science refers to the attack on disinterested knowledge in favour of measurable outcomes, accountability, commercialization and applicability. See Philip Mirowski, Science-Mart: Privatizing American Science, Cambridge, MA: Harvard University Press, 2011.

15 See Gordon M. Burghardt and Harold A. Herzog Jr, 'Beyond conspecifics: is Brer Rabbit our brother?', BioScience (1980) 30, pp. 763-768.

16 See Benjamin D. Sachs to Beach, 12 November 1976, Frank A. Beach papers, Akron, OH, Box M1283, Folder 5; Gordon M. Burghardt to Aronson, 5 February 1981, Department of Animal Behavior, American Museum of Natural History, Unprocessed Collection, Box 3. Singer held that scientists targeted by animal liberation were not 'especially evil or cruel people' but were representative of 'the mentality of speciesism'. See Peter Singer, Animal Liberation: A New Ethics for Our Treatment of Animals, New York: New York Review of Books, 1975, pp. 35-36.

17 On the persistence of antivivisection (albeit in more diffuse forms) during this era see Susan E. Lederer, 'Political animals: the shaping of biomedical research literature in twentieth-century America', Isis (1992) 83, pp. 61-79.

18 See Aronson to Donald E. Clark, 3 February 1977, DAB, American Museum of Natural History, Unprocessed Collection, Box 11; Director Thomas Nicholson spoke about 'our bout with extremist and irrational anti-vivisectionists and animal rightists'. Nicolson to Gordon M. Burghardt and Harold A. Herzog Jr, 3 December 1980, DAB, American Museum of Natural History, Unprocessed Collection, Box 3.

19 The movement was strongest in Britain, culminating in the 1876 Cruelty to Animals Act. See Richard D. French, Antivivisection and Medical Science in Victorian Society, Princeton, NJ: Princeton University Press, 1975. On the moral economy of the British vivisectionists see Rob Boddice, 'Vivisecting Major: a Victorian gentleman scientist defends animal experimentation, 1876-1885', Isis (2011) 102, pp. 215-237. 
non-human animals) needed protection because of their common capacity for feeling. Emotion was central to this 'sentimental liberalism', in the form both of the ability of the defenceless to experience pain and of the heightened empathy on the part of their protectors to defend these weaker creatures. ${ }^{20}$ The primacy of feeling, combined with the prevalence of women as advocates, led many scientists to dismiss the humane movement as anti-scientific and irrational. ${ }^{21}$ In contrast, Singer favoured a tough-minded utilitarian calculus of competing interests to distance the movement from an earlier 'feminine' sentimentalism. ${ }^{22}$

Aronson's naivety was due to the historical success of American medical researchers in crafting the laws regulating the use of laboratory animals to insulate their science from antivivisectionist critics. ${ }^{23}$ Turn-of-the-century physiologists articulated an ethical code that combined Judaeo-Christian theology with utilitarianism. The core assumption was theological: humanity had a God-given dominion over 'brute creation', to make use of it for his benefit. ${ }^{24}$ There was some ambivalence over whether this condition was truly a 'right' or simply represented humanity's 'power', but this distinction was largely moot. ${ }^{25}$ American physiologists insisted that it was 'unreasonable to wage a humanitarian warfare against the only kind of pain giving practice that has for its object the relief of pain'. ${ }^{26}$ They recognized the close kinship between humans and other animals in terms of physiology and even psychology; their entire science depended on this assumption. These scientists did not deny that laboratory animals sometimes experienced pain. In 1897, physiologist Henry Bowditch explained, 'No one pretends that vivisections can be conducted without more or less discomfort to the brute creature. ${ }^{27}$ Yet the infliction of such pain had virtuous ends. Some animals were expected to suffer to benefit the rest of creation. ${ }^{28}$

In 1906, physiologist C.F. Hodge went even further, noting that by testing various therapeutics through everyday medical practice, physicians were 'with perfect right and of necessity, "experimenting", often painfully too, on thousands of human beings every year'. At the same time, the state destroyed potentially valuable stray cats and

20 Susan J. Pearson, The Rights of the Defenseless: Protecting Animals and Children in Gilded Age America, Chicago: The University of Chicago Press, 2011.

21 On the intersection of feminism and antivivisectionism see Coral Lansbury, The Old Brown Dog: Women, Workers, and Vivisection in Edwardian England, Madison: University of Wisconsin Press, 1985.

22 See Singer, op. cit. (16), pp. viii-ix. For a critique of 1970s animal rights theory on these grounds see Josephine Donovan, 'Animal rights and feminist theory', Signs (1990) 15, pp. 350-375.

23 Donald A. Dewsbury, 'Early interactions between animal psychologists and animal activists and the founding of the APA Committee on Precautions in Animal Experimentation', American Psychologist (1990) 45, pp. 315-327.

24 On the theological roots of this attitude see Keith Thomas, Man and the Natural World: Changing Attitudes in England, 1500-1800, London: Allen Lane, 1983.

25 See the telling slip in W. Pallin to J.H. Galliger, 25 January 1896, Walter B. Cannon Papers, Countway Medical Library, Boston, MA, Box 24, Folder 289. Hereafter cited as Cannon Papers.

26 Massachusetts Medical Society, 24 February 1896, Cannon Papers, Box 24, Folder 289.

27 H.P. Bowditch to J.H. Gallinger, 12 June 1897, Cannon Papers, Box 24, Folder 290.

28 On the adoption of mice due to concerns about pain see Karen Rader, Making Mice: Standardizing Animals for American Biomedical Research, 1900-1955, Princeton, NJ: Princeton University Press, 2004, pp. 35-36. 
dogs without anyone's benefit. ${ }^{29}$ It was the scientist's duty to minimize such waste. Key to Hodge's argument was that all animals benefited from advances in physiology through the greater refinement of medical and veterinary knowledge. He put the utilitarian calculus of pain most boldly: 'It is sheer maudlin sentimentality which would try to exempt dogs and cats from their just share of the burdens of life. ${ }^{30}$ Medical progress for the many required that a few individual brutes must occasionally suffer physical pain even if it was not in their immediate interest.

One of the most contentious issues in these legislative battles was over who should ensure animal welfare. Were laboratories secretive spaces accessible only to invited scientists, or public institutions open to the police, humane societies or ordinary citizens? In the United States, Walter Cannon was the chief advocate for the autonomy of medical researchers from outside surveillance. The Harvard physiologist insisted that closed laboratories were the only acceptable option. This campaign was part of his broader commitment to medical professionalization following the 1910 Flexner report. $^{31}$ Cannon's solution was the posting within the laboratory of five principles enforced by the moral authority of the laboratory head, making 'a man who usually stands well in the community, and whose judgment and caution can be relied upon, directly answerable for the humane conduct of experimentation in his department'. ${ }^{2}$ Proper conduct hinged upon this elevated form of expertise to evaluate the propriety of using animals in experiments and pedagogical demonstrations. By shutting down unregulated schools, scientifically trained medical educators could ensure that best practices were maintained.

Compared with medical researchers, psychologists were considerably less concerned with antivisectionists. The American press criticized many turn-of-the-century comparative psychologists for their cruelty. However, the 1924 creation of the American Psychological Association's Committee on Precautions in Animal Experimentation came at Cannon's behest. The impetus was his involvement with the Committee for Research in Problems of Sex (CRPS). In reviewing an article by a funded psychologist, Calvin Stone, the discussion of surgery without any mention of anaesthetic alarmed Cannon. ${ }^{33}$ Fearing reprisal from antivivisection groups, Cannon urged the journal's editor, Robert Yerkes, to ensure that future authors were more cautious and would include details about the anaesthetic process. ${ }^{34}$ Stone's casualness about this issue spoke to the obliviousness of his generation of psychologists regarding the threat of antivivisectionists to their research. What had been a career-long, acute worry for Cannon was a largely invisible, formalized procedure for the next generation. ${ }^{35}$ For Stone and

29 On animal control as governance see Jessica Wang, 'Dogs and the making of the American state: voluntary association, state power, and the politics of animal control in New York City, 1850-1920', Journal of American History (2012) 98, pp. 998-1024.

30 C.F. Hodge to Harold Ernst, 28 February 1906, Cannon Papers, Box 261, Folder 313.

31 On the Flexner Report see Paul Starr, The Social Transformation of American Medicine, New York: Basic Books, 1982, pp. 118-123.

32 Cannon to Harvey Cushing, 28 November 1908, Cannon Papers, Box 28, Folder 334.

33 Dewsbury, op. cit. (23), pp. 320-324.

34 Cannon to Yerkes, 22 January 1924, Cannon Papers, Box 77, Folder 1043.

35 On the influence on antivivisectionists on medical writing conventions see Lederer, op. cit. (17). 
later Aronson, the use of anaesthetic was so routine it was not worth mentioning. Similarly, the animal's capacity to experience pain was tacitly recognized, but given little attention.

\section{The psychobiology of individuality and development}

Sex was central to the comparative psychology conducted at the AMNH. Beginning with the zoologist G. Kingsley Noble in the 1930s, its scientists had studied the role of cortical and gonadal regulation of sexual behaviour in countless species from fish to birds to mammals. These experiments involved a host of surgical interventions: brain lesions, castrations and hormone injections. The aim was to explain how the nervous and endocrine systems worked together to manifest and control sexual and social behaviours, as well as to put these behavioural patterns in an evolutionary perspective. ${ }^{36} \mathrm{AMNH}$ scientists used a wide variety of animals because they placed greater emphasis on species-specific behaviours compared with most of their peers. ${ }^{37}$

In an era prior to large-scale government patronage for science, sex had been a pragmatic way to fund comparative psychology. There was little money to support the field studies these scientists preferred, but the CRPS was willing to fund experiments modelled on biomedical methods. Aronson first opted to work with cats in the hopes that it would 'hold the interest of the Sex Committee'. ${ }^{38}$ In the post-war era, AMNH behavioural scientists were quite successful in securing foundation, NIH and military support for their efforts. Vaguely grounded in the notion that such experiments served as models for either infant development or various mental illnesses, Aronson largely adhered to the Cold War ideals of value-neutrality and pure research. Because of abundance of funding and the mid-century prestige of science, he spent most of his career relatively insulated from the need to justify his research in strictly pragmatic terms with immediate deliverables.

These experiments depended on regular gifts of synthetic hormones from the Schering Corporation. Schering employees offered advice about proper dosages as well as alternative compounds for conducting the experiments. In return, Aronson provided clinical and experimental feedback on the effects of different preparations on his animals. ${ }^{39}$ However, Aronson was not an industrial scientist, conducting critical research focused on the development of new products or applications. The company did not set his research agenda, nor did it define which problems he should pursue. Instead, there was a broad alignment of concerns between the scientists at the museum and at

36 Erika Milam, Looking for a Few Good Males: Female Choice in Evolutionary Biology, Baltimore: Johns Hopkins University Press, 2010, pp. 54-79.

37 Michael Pettit, Darya Serykh and Christopher D. Green, 'Multispecies networks: visualizing the psychological research of the Committee for Research in Problems of Sex', Isis (2015) 106, pp. 121-149.

38 Aronson to Beach, 27 April 1948, DAB Unprocessed Collection, Box 3.

39 Aronson to Edward Henderson, director, 22 March 1948; Aronson to Schwenk, 28 December 1948; Aronson to Tislow, 11 January 1952; Tislow to Aronson, 21 January 1952, DAB Unprocessed Collection, Box 12. 
Schering, and this connection helped Aronson conceive of his own psychobiology as contributing the ongoing refinement of therapeutics. ${ }^{40}$

One of Aronson's primary responsibilities as a curator at the AMNH was communicating the science of animal behaviour to the public. This took the form of exhibits, films, magazine articles and answering inquiries sent to the museum. His work with cats began with his attempt to record the mating calls of different species as part of an exhibit on animal courtship. ${ }^{41}$ This public role gained prominence as the museum changed over the course of the twentieth century from a largely research institution into a wonderfilled play land aimed increasingly at children. ${ }^{42}$ Certainly not a household name, Aronson and his research did feature in the New York press throughout his career.

The first publicly circulated account of the AMNH's cat research appeared in a 1949 New York Herald Tribune article that asked 'What makes a tomcat howl?'. It featured a rather bemused Aronson (stopwatch and notebook at the ready) face-to-face with the equally inquisitive Eunie. It is unclear who is observing whom in this instance. Aronson studies Eunie, but the cat returns the gaze. There is no mention of surgical apparatus or pharmaceutical products, even though Eunie (short for eunuch) was a pre-puberally castrated cat later given testosterone injections. ${ }^{43}$ Despite avoiding such matters, the article remains very much a story about how laboratory technology can disentangle the social and sexual behaviour of the city's most familiar inhabitants. By recording and measuring the wails and poses of ten toms borrowed from 'willing friends', Aronson's team determined that what most New Yorkers assumed was 'a love call' was instead the masculine 'fighting call'. ${ }^{44}$

Aronson introduced his research to the public using an example familiar to New Yorkers as the cat's howl that had been a fixture of the city's soundscape for over a century. An 1871 article remarked on the species' 'almost universal presence before the public in this City'. ${ }^{45}$ By 1883, New York was recognized as 'one of the largest cat producing districts of the whole country', with a greater density of strays residing along its back fences than Philadelphia or Boston. ${ }^{46}$ The common practice of families abandoning their cats when they went on vacation led to this abundance. ${ }^{47}$ Not everyone cherished the omnipresence of these critters. In 1893 the American Society for the Prevention of Cruelty to Animals (ASPCA) clashed with the Midnight Band of Mercy, a group of women who went about chloroforming noisy strays in the name of reclaiming the night for human sleep. When arrested, the band's leader, Sarah J. Edwards, assumed the humane mantle, insisting that these abandoned animals met

40 Cf. Shapin, op. cit. (13), Chapter 5.

41 Aronson to Beach, 4 June 1947, DAB Unprocessed Collection, Box 3, DSCF2962-63.

42 See Gregg Mitman, Reel Nature: America's Romance with Wildlife on Film, Cambridge, MA: Harvard University Press, 1999 , pp. 59-84.

43 See Aronson to Tislow, 11 December 1952, DAB Unprocessed Collection, Box 12.

44 John O'Reilly, 'What makes a tomcat howl? Scientists try to find the answer', New York Herald Tribune,

26 April 1949, Central Administrative Archive, AMNH, Box 1196.1, Folder 1948-1952.

45 'Cats and their owners', New York Times, 14 November 1871, p. 5.

46 'An opening for cats', New York Times, 6 May 1883, p. 8.

47 Katherine C. Grier, Pets in America: A History, Chapel Hill: University of North Carolina Press, 2006, p. 37. 
a painless end and that the ASPCA neglected its responsibility of attending to these starving and homeless creatures. ${ }^{48}$

These long-standing patterns of interspecies cohabitation enabled distinct forms of necropolitics towards different kinds of animals which informed Aronson's research. Newspaper stories repeatedly drew connections between the species and the city. Cats were bound to New York's built form: an animal suited to a world of cramped dwellings and alleyways. ${ }^{49}$ Adjacent to but distinguished from vermin like rats, pigeons and cockroaches, alley cats nevertheless represented the rougher side of urban life. ${ }^{50}$ These years witnessed a broad shift from a largely utilitarian evaluation of animals in terms of their economic use towards seeing certain species as invaluable companions. The focus of veterinary medicine shifted from ensuring agricultural livestock's maximum yield to attending to the health and comfort of household pets. ${ }^{51}$ This sentimentalism notwithstanding, cats remained somewhat distinct from dogs, the most cherished American pet. Cats remained aloof creatures where dogs signified loyalty and affection with a long history of close human-animal working relationships. A valued member of the urban household because of their talents for pest control, cats symbolized independence, autonomy and self-reliance. ${ }^{52}$

Indeed, an oscillation between cats as experimental objects requiring emotional distance and as pets in need of care animated much of the AMNH psychobiology. ${ }^{53}$ The knowledge derived from affectionate pet ownership informed how these scientists understood cats as models of sexual behaviour. When Aronson began to study them, he contacted his former colleague Frank Beach, an expert in mammalian behaviour. Beach related the results of an abandoned experiment, but also detailed how his house cat, Shadow, exhibited 'most of the copulatory pattern using a pillow or folded blanket as a "love object"'. Shadow's behaviour amused and confounded Beach. He slyly noted how his pet 'is unfamiliar with the fact that he should not be doing anything of the sort because (1) he is a castrate and (2) he is supposed to show such behavior only in the presence of the biologically adequate stimulus (Beach 1947, Psychosomat. Med)'. ${ }^{54}$ Wilful cats were so independent-minded that they brazenly overturned one's prized theories.

48 'Meow! Eow! Spat! No more', New York Times, 30 June 1893, p. 12; 'She's a defender of cats', New York Times, 20 July 1893, p. 9; 'Her work not appreciated', New York Times, 6 October 1893, p. 9; 'Mrs. Edwards means to fight', New York Times, 7 October 1893, p. 9. Her trial occurred as the ASPCA was successfully lobbying for legal authority over the city's lost and stray animals. See Wang, op. cit. (29), 1009.

49 Paul Montgomery, 'Hard times for alley cats', New York Times Sunday Magazine, 12 April 1964, p. 49.

50 On vermin and necropower see Clapperton Chakanetsa Mavhunga, 'Vermin beings: on pestiferous animals and human game', Social Text (2011) 29, pp. 151-176.

51 Susan D. Jones, Valuing Animals: Veterinarians and Their Patients in Modern America, Baltimore: Johns Hopkins University Press, 2003, pp. 115-140; Grier, op. cit. (47); Donna Haraway, When Species Meet, Minneapolis: University of Minnesota Press, 2007.

52 Richard Attridge, 'Cats can take people or leave them alone', Saturday Evening Post, 27 March 1954, pp. 10-12.

53 Such relations were not unique to the AMNH. See Daniel P. Todes, Pavlov's Physiology Factory: Experiment, Interpretation, Laboratory Enterprise, Baltimore: Johns Hopkins University Press, 2001.

54 Beach to Aronson, 6 June 1947, Unprocessed Collection, Box 2. 
Aronson found maintaining a healthy laboratory colony a constant challenge. The first obstacle was acquiring the cats themselves. A 1953 Saturday Evening Post article suggested that Aronson obtained his virile male subjects from the city's alleyways. The magazine explained that this decision reflected Aronson's response to criticisms of psychology's overreliance on laboratory animals whose 'countless generations have been raised in cages and it seems likely their sophisticated responses to phenomena do not at all mirror the responses of country cousins which live in a wild state'. ${ }^{55}$ The trope of the scientists stealing animals from the street came from the antivivisection literature, namely William Randolph Hearst's newspapers, which suggested that people's pets were regularly at risk from disreputable researchers. ${ }^{56}$ The Evening Post had a different message: the urban alley substitutes for the state of nature, an answer to the overrefinement of domesticity and domestication. These males benefit from their captivity. 'Graduated from garbage cans to Grade A provender, these sleek and well-fed Toms set up a raucous chorale whenever the door to the attic domain is opened. They never had it so good. 57 Considering the prominence of the cat-napping story in other media, it is unclear whether Aronson ever collected alley cats. His existing correspondence does not suggest this as it includes inquiries and updates seeking to identify dealers and by the early 1950 s a breeding programme had become part of life in the colony. ${ }^{58}$ Another major challenge was keeping disease in check. Mortality rates ran high in the colony's early years. The large number of animals kept in close, common quarters made disease a major threat. Things improved markedly in 1949 with a vaccination programme for distemper. ${ }^{59}$ Because of the costs involved, nutrition was always a salient issue. Initially the cats were maintained on a diet of horsemeat, but in 1952 Aronson turned to artificial feed, beginning in collaboration with Notre Dame nutritionist Thomas Luckey to test the effectiveness of his CatSNAC product. ${ }^{60}$

AMNH psychologists insisted that they cared about the animals with which they worked. ${ }^{61}$ In response to a 1973 letter, Aronson insisted that his laboratory complied with existing regulations and the standards set by the ASPCA. Federal authorities always gave top ratings following their regular inspections of the facilities. He acquired cats from authorized dealers rather than pounds in order to avoid accidentally using someone's pet. They kept the animals in clean, well-ventilated and air-conditioned rooms and the cats received regular medical attention such that 'they are in excellent

55 Milton MacKaye, 'Biggest free show in New York', Saturday Evening Post, 28 February 1953, pp. 22, $59-67,64$.

56 Lederer, op. cit. (17), pp. 63-64.

57 MacKaye, op. cit. (55), p. 64.

58 Beach to Aronson, 6 June 1947; Aronson to Beach, 3 November 1949, DAB Unprocessed Collection, Box 3.

59 Aronson to Beach, 3 November 1949, DAB Unprocessed Collection, Box 3. Such vaccinations only became a routine aspect of pet care starting in the 1950s. See Jones, op. cit. (51), 132-134.

60 Aronson to T.D. Luckey, 24 July 1952; Luckey to Aronson, 23 September 1952, DAB Unprocessed Collection, Box 7.

61 On the ideal of animal welfare see Abigail Woods, 'From cruelty to welfare: the emergence of farm animal welfare in Britain, 1964-71', Endeavour (2012) 36, pp. 14-22. 
health as indeed they would have to be for studies of mating behavior'. ${ }^{62} \mathrm{He}$ explained that his research involved long-term observation, sometimes over a number of years, and that animals were reused, returned to the dealer or put to sleep once the experiment had ended. Good science required good care. Starting with Noble in the 1930s, AMNH scientists had laboured to re-create such 'normal' environments for their experimental animals. ${ }^{63}$ Aronson's colleague Ethel Tobach insisted that

the cats in our cages were really very well suited for the life that they led. They had a lot of interaction with people and with each other that kept them very healthy and very good so that when people said we were doing bad things with the cats it was very bad. Because Aronson actually invented a cage in which the cats had a shelf to sit on, and they were let out of the cage when the cages were being cleaned and stuff like that. It was a very, very different approach to cats because they both loved cats very much. ${ }^{64}$

Where animal liberationists emphasized the primacy of Aronson's necropower in the form of his ability to kill, maim and torture animals at will, Tobach articulated his stewardship.

This attentiveness to care resonated with how these psychobiologists defined themselves as the most humane and humanistic interpreters of animal behaviour in postwar America. This humanism found expression in their political commitments to social justice. Schneirla organized American psychologists' response to the Spanish Civil War while Tobach led the Genes \& Gender collective's opposition to the racial and sexual politics of sociobiology in the 1970s. ${ }^{65}$ These scientists positioned themselves as occupying the space between the reductionism of the behaviourists who saw animals as interchangeable machines and a Nazi-tinged ethology grounded in the essentialism of innate instincts programmed into the nervous system at birth. Aronson explained to a high-school student in 1952 that this research represented a genuine alternative, one focused on 'the processes by which these particular behaviour patterns which people like to think of as "instinctive" actually develop in the individual'. ${ }^{66}$

This dual focus on development and animal individuality made AMNH psychobiology unique. Many of Aronson's own scientific reports emphasized the animal's emotional life and personalities. ${ }^{67}$ His publications on sexual behaviour included case

62 Aronson to Keith David, 6 February 1973, DAB Unprocessed Collection, Box 2.

63 See Erika Milam, “"The experimental animal from the naturalist's point of view”: behavior and evolution at the American Museum of Natural History, 1928-1954', Transactions of the American Philosophical Society (2009) 99, pp. 157-178.

64 Ethel Tobach interview by Alexandra Rutherford and Wade Pickren, Psychology's Feminist Voices Oral History and Online Archive Project, 13 November 2006, at www.feministvoices.com/ethel-tobach.

65 Lorenz J. Finison, 'Psychologists and Spain: a historical note', American Psychologist (1977) 32, pp. 1080-1084; Alexandra Rutherford, Kelli Vaughn-Blount and Laura C. Ball, 'Responsible opposition, disruptive voices: science, social change, and the history of feminist psychology', Psychology of Women Quarterly (2010) 34, pp. 460-473.

66 Lester Aronson to David Bass, 18 March 1952, DAB, Correspondence, Administrative Records, American Museum of Natural History, Box 3, Folder 1.

67 For his contemporaries' concerns about Aronson's overemphasis on animal individuality see C.R. Carpenter to Frank A. Beach, 29 March 1957; Beach to Aronson, 14 February 1957, C.R. Carpenter Papers, Pennsylvania State University, Box 7. 
histories of individual animals, such as a 1949 paper on a single cat's 'nocturnal emissions' that speculated about feline (sex) dreams. Throughout the paper, he turned to the Kinsey report to shed light on the cat's behaviour. ${ }^{68}$ Early publications identified individual cats by name, in spite of existing conventions to the contrary. ${ }^{69}$ This was in marked contrast to the almost wholly statistical approach Aronson took when analysing the sexual behaviour of fish. ${ }^{70}$ In correspondence, he repeated how the results of the cat experiments overwhelmed him with the abundance of individual responses that fit no clear theory or headline-grabbing conclusions. Instead, his knowledge of cat sexuality focused on documenting individual variation through long-term cohabitation and experimentation. The goal became elucidating this very complexity for its own sake. This commitment entailed longitudinal studies of the cats over many years with little demand for immediate or practical results.

$\mathrm{AMNH}$ psychologists understood themselves as the curators of those things overlooked and neglected by other students of behaviour. Aronson came to see cats as complicated living tools whose affordances as a species allowed him to model the complexity of the dynamic interactions between individual experience and neural and endocrine regulatory mechanisms. In contrast, the rats and birds favoured by their intellectual opponents seemed to operate as technologies for reductionism. Cats helped materialize in the laboratory the relational character of inner and outer environments. The result was an 'epigenetic' standpoint that saw each stage of an individual's development as the interaction between organism and environment. ${ }^{71}$

\section{Sex, death and taxes: the moral world of animal liberation}

When first confronted by animal liberationists in 1976, the museum initially defended the cat programme by championing the pure-science ideal. Director Thomas Nicholson insisted that the AMNH had the 'freedom to study whatever it chooses without regard to its demonstrable practical value'. ${ }^{72}$ It was precisely this argument that Spira's campaign sought to undercut. Understanding his strategy historically involves documenting how events were framed by rhetoric and imaginary from both the new social movements and the new, post-1970s conservative anti-statism.

The placards carried outside the museum during the weekend protests included such slogans as 'Let my people go!' and 'Voice of the voiceless', invoking the language of

68 Lester R. Aronson, 'Behavior resembling spontaneous emissions in the domestic cat', Journal of Comparative and Physiological Psychology (1949) 42, pp. 226-227. The journal's editor insisted on the revised title. See Calvin Stone to Aronson, 29 November 1948, DAB, American Museum of Natural History, Unprocessed Collection, Box 7.

69 See Jay S. Rosenblatt and Lester R. Aronson, 'The decline of sexual behavior in male cats after castration with special reference to the role of prior sexual experience', Behaviour (1958) 12, pp. 285-338. On avoiding individual names see Lederer, op. cit. (17), p. 73.

70 Milam, op. cit. (36), p. 77.

71 Lester R. Aronson, 'Levels of integration and organization: a reevaluation of the evolutionary scale', in Gary Greenberg and Ethel Tobach (eds.), Evolution of Social Behavior and Integrative Levels, Hillsdale, NJ: Lawrence Erlbaum Associates, 1988, pp. 57-81.

72 Nathaniel Sheppard Jr, 'Cats' mutilation laid to Museum', New York Times, 19 July 1976, p. 31. 
1960s social movements. Newsweek noted Spira's long-time union activities and his having 'made the Mississippi scene during the civil-rights days'. ${ }^{73}$ These movements succeeded in redefining public sensibilities about what counts as suffering across the social spectrum. This included a new sensitivity about what counted as intolerable physical or psychological pain. ${ }^{74}$ The civil rights struggle not only challenged the injustice of "separate but equal' institutions, but also documented the psychological damage created by this legally sanctioned inequality. ${ }^{75}$ Similarly, radical feminists deployed 'consciousness raising' as a strategy for translating supposedly personal matters (such as reproductive choice or sexual assault) into common concerns by collecting the evidence of experience. ${ }^{76}$

Singer was very much aware that he was writing in the civil rights era and worked to mobilize the force of history in support of animal liberation. He placed consciousness raising at the core of the new social movements since they entailed the revelation of previously hidden forms of discrimination. Every social movement had constituted 'an expansion of our moral horizons', as unmarked privilege became intolerable. Black liberation, gay liberation and women's liberation had each in turn drawn into public view forms of suffering and suppressed collective traumas. Singer insisted that these movements erred in grounding rights in cognitive equality; a tentative scientific claim. Instead, he famously turned to a shared capacity to experience physical pain regardless of intelligence or language, an argument he traced back to Jeremy Bentham. Because of this capacity, all organisms had weighable interests in any utilitarian calculus. ${ }^{77}$ Where early twentieth-century physiologists insisted that medical research was the most humanitarian example of animal suffering, Singer pointed to scientific experiments as particularly vulnerable to attack because of the contradiction at the heart of their justification. Where the meat eaters need not identify with the food they consumed, biomedical research relied on animal models due to cross-species kinship with humans. He singled out psychologists as worthy of particular scrutiny, noting that their experiments numbered among 'the most painful', their results 'very often trivial and obvious'. The entire field rested on the paradox of assuming a close affinity across species lines while denying such connections in the next moment. ${ }^{78}$

Aronson and Cooper rejected 'the quasi-moralistic claim that animals have "rights" equal to the sociopolitical rights of women and minorities' ${ }^{79}$ Yet the affinity between animal rights and other social movements was a genuine, if fraught, one. Efforts of both superpowers in the Cold War to improve material conditions and education for

73 Peter Gwynne and Stephen G. Michaud, 'Cat fight', Newsweek, 8 November 1976, p. 100.

74 Keith Wailoo, Pain: A Political History, Baltimore: Johns Hopkins University Press, 2014.

75 Daryl Michael Scott, Contempt and Pity: Social Policy and the Image of the Damaged Black Psyche, 1880-1996, Chapel Hill: University of North Carolina Press, 1997; John P. Jackson, Social Scientists for Social Justice: Making the Case against Segregation, New York: New York University Press, 2001.

76 See Michelle Murphy, Sick Building Syndrome and the Problem of Uncertainty: Environmental Politics, Technoscience, and Women Workers, Durham, NC: Duke University Press, 2006, pp. 62-64.

77 Peter Singer, 'Animal liberation', New York Review of Books, 5 April 1973.

78 Singer, op. cit. (16), pp. 36, 42, 49.

79 Lester D. Aronson and Madeline L. Cooper, 'Letter', Science (19 November 1976) 194, pp. 784-786, 786. 
their citizens heightened their cultural expectations, which inspired the international counterculture that criticized the failures and contradictions of such aspirations. ${ }^{80}$ In the comparatively affluent postwar societies, even non-humans deserved to have their interests protected. They were no longer the raw materials that made human life sustainable, but companions whose individuality demanded recognition.

However, there was a historical irony at play, one not readily acknowledged by either side in the debate. The animal liberationists' emphasis on each organism's agency owed a considerable debt to research in developmental psychobiology like Aronson's which focused on animal individuality. Just as Cold War politicians raised the expectations of their citizens, so cognitive scientists, ethologists and their popularizers raised expectations about animal intelligence, emotion and communication, especially when it came to primates and cetaceans. ${ }^{81}$ In other words, Aronson's own science emphasized close kinship across species lines.

During the 1970s, strands of the peace and liberation movements morphed into a variety of projects championing human rights and ecological concerns on the global stage. In contrast to the totalizing transformations envisioned by the counterculture, organizations such as Amnesty International, Médecins sans Frontières, and Greenpeace pursued gradualist strategies of focusing on concrete cases, gathering information and seeking to apply the rule of (international) law. ${ }^{82}$ Greenpeace exemplified this new transnational approach as the originally Canada-based organization sought to curtail American and French nuclear testing in international waters. In 1975, Greenpeace turned its direct-action approach to the abolition of the commercial whale hunt. In addition to shifting from state to corporate targets, this campaign represented an uneasy marriage of ecology and animal liberation. ${ }^{83}$ With its emphasis on protecting individual life (albeit now across the species line), animal rights fit more squarely within the political ideology of the 1960s social movements compared with the contemporaneous environmentalism that often sought to undercut the presumption of possessive individualism. ${ }^{84}$ Moreover, the New York City protests that sought to prevent the mutilation of future cats resonated with another of Greenpeace's iconic projects: their effort to end the killing of (highly photogenic) seals by Newfoundland fishermen. ${ }^{85}$

80 Jeremi Suri, 'The rise and fall of an international counterculture, 1960-1975', American Historical Review (2009) 114, pp. 45-68.

81 Donna J. Haraway, Primate Visions: Gender, Race, and Nature in the World of Modern Science, New York: Routledge, 1989, pp. 133-185; Mitman, op. cit. (42), pp. 157-179; Frank Zelko, 'From blubber and baleen to Buddha of the deep: the rise of the metaphysical whale', Society and Animals (2012) 20, pp. 91-108; Marga Vicedo, The Nature and Nurture of Love: From Imprinting to Attachment in Cold War America, Chicago: The University of Chicago Press, 2013, pp. 43-68.

82 On 'post-citizenship' social movements see James M. Jasper, The Art of Moral Protest: Culture, Biography, and Creativity in Social Movements, Chicago: The University of Chicago Press, 1997, pp. 7-8.

83 Frank S. Zelko, Make It a Green Peace! The Rise of Countercultural Environmentalism, New York: Oxford University Press, 2013, pp. 161-230.

84 On this tension between environmentalism and other 1960s social movements see Adam Rome, "Give Earth a chance": the environmental movement and the Sixties', Journal of American History (2003) 90, pp. 525-554.

85 Zelko, op. cit. (83), pp. 231-274. 
Founded in 1961, Amnesty International sought to raise the profile of persons facing imprisonment, torture or execution for non-violent acts of conscience. ${ }^{86}$ The organization's approach to international justice gained in prominence throughout the 1970s after the failure of more state-centred utopian projects. ${ }^{87}$ Rather than focusing on broad humanitarian crises facing populations, they channelled attention through the plight of particular individuals. Figure 1 traces references to 'torture' in the New York Times, the newspaper where the museum's opponents placed their more visible advertisements. Although the Times included discussions of torture from its inception in the 1850 s, the term saw an increase of over 50 percent in prevalence in the 1970 s compared with previous decades. Substantively, these stories largely focused on the 'rule of pain' pursued by various Latin American military dictatorships and paid particular attention to the regimes' 'expertise and equipment': secret detention rooms, isolation, maiming and mutilation. ${ }^{88}$

An important part of this human rights movement was an elevated awareness about the role of psychology in the practice of torture via 'sensory deprivation' and 'solitary confinement', words long used by AMNH psychobiologists to describe their research. ${ }^{89}$ These terms had become tied to specific research programmes within psychology while carrying very different meanings in the wider public sphere. Alongside intelligenceagency-funded research into interrogation techniques, these experiments played a central role in the American reception of ethology. ${ }^{90}$ In these debates, AMNH scientists pursued deprivation experiments due to scepticism about instincts and their desire to demonstrate the inability of such experimental designs to isolate the innate. ${ }^{91}$

'Torture' had been antivivisectionists' keyword, but the concept gained a new valence due to the internationally ascendant human rights movement. An advertisement paid for by Spira's Society for Animal Rights conjured images reminiscent of Amnesty International's exposés of locked-away dissidents: 'The American Museum of Natural History has one room that's not on display: an experimental laboratory filled with suffering animals. ${ }^{\prime 2}$ In May 1977, the Millennium Guild took out a full-page advertisement whose focal point

86 At the same time, the United States was instituting unprecedented levels of incarceration. See Heather Ann Thompson, 'Why mass incarceration matters: rethinking crisis, decline, and transformation in postwar American history', Journal of American History (2010) 97, pp. 703-734.

87 Samuel Moyn, The Last Utopia: Human Rights in History, Cambridge, MA: Harvard University Press, 2012.

88 Jean-Pierre Clavel, 'Torture, an official way of life in 30 countries: nations are now exchanging expertise and equipment', New York Times, 4 August 1974, p. 155; Jonathan Kandell, 'Church group reports torture of Chilean prisoners', New York Times, 17 May 1974; Jeri Laber, 'Torture and death in Uruguay', New York Times, 10 March 1976.

89 On 'solitary confinement' see Schneirla in 'Annual Report, 1956-1957', DAB Unprocessed Papers, Box 2. On 'sensory deprivation' see Aronson in 'Animal Behavior: Annual Report - 1961-1962', DAB Unprocessed Papers, Box 2.

90 On the influence of psychology on subsequent interrogation techniques see Alfred McCoy, A Question of Torture: CIA Interrogation from the Cold War to the War on Terror, New York: Metropolitan, 2006, pp. 2159; Mical Raz, 'Alone again: John Zubek and the troubled history of sensory deprivation research', Journal of the History of the Behavioral Sciences (2013) 49, pp. 379-395.

91 See Vicedo, op. cit. (81), pp. 95-120.

92 New York Times, 2 July 1976, p. 44. 


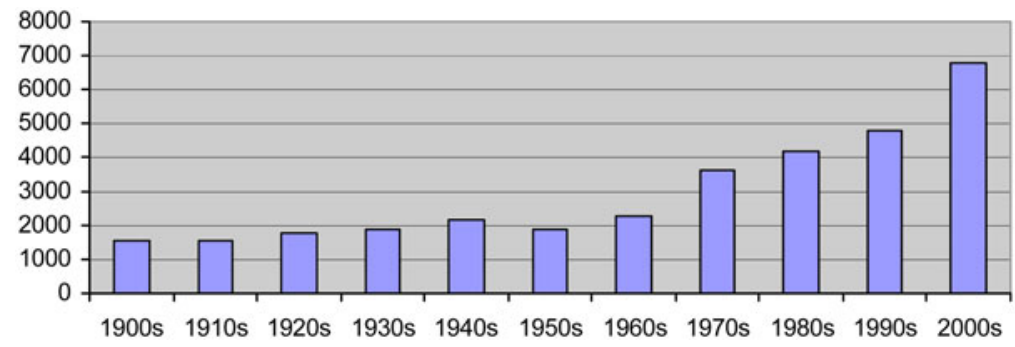

Figure 1. References to torture in the New York Times.

was a cat in a blinding machine. The text frequently mentions the mutilations and torture faced by the AMNH cats, 'living in an artificial environment of alternating boredom and terror'. Talk of 'sound-proof labs' as secret torture rooms hidden 'behind locked doors' cast the animals in a role analogous to that of the Latin American disappeared, even though the concept of the cat's 'rights' was never overtly mentioned. ${ }^{93}$

The sexual content of the experiments made them a vulnerable target of criticisms of animal research. Aronson understood himself as contributing towards more liberal sexual attitudes, describing a career-long struggle against the editorial 'prudes in scientific publishing' to get his cat papers published. ${ }^{94}$ The New York Times reported that protestors' placards read 'Castrate the Scientists', 'Aronson, What Does Your Psychiatrist Think of Your Sexual Experiments?' and 'Sadists Play - Our Taxes Pay'. ${ }^{95}$ These slogans resonated with a heightened awareness about the damaging effects of sexual abuse and sexual coercion. At the same time, the slogans represented a slippage between the sexuality of experiments from the cats as scientific objects to the scientist as curious knower. The protesters took recourse to using non-normative sexualities as a strategy to delegitimize a political opponent. Retroactively describing his tactics, Spira insisted that it is 'a mistake to claim that research scientists get their jollies from torturing animals', and that his goal was never to vilify individual scientists, but both strategies featured prominently in the AMNH campaign. ${ }^{96}$ Yet the signs invoke Aronson's supposed sexual pleasures, his secret perversity. The protest could still draw on the intuition that there is something inherently wrong with the government-funded research on sexuality.

Yet the experiments' sexual propriety was also refracted through shifting interspecies relations. Where the image of the tough and robust alley cat predominated at midcentury, a new understanding came to the fore by the mid-1970s, one intertwined with the demands of urban social and sexual life. The construction of massive apartment buildings destroyed many of the alleys and back fences where strays had once flourished.

93 'Stop the cat-torture at the American Museum of Natural History', New York Times, 3 May 1977, p. 33.

94 Aronson to Donald A. Dewsbury, 27 November 1979, DAB, American Museum of Natural History, Unprocessed Collection, Box 2.

95 '200 stage protest at Gracie Mansion over cat research', New York Times, 22 August 1976, p. 41.

96 Spira, op. cit. (8), pp. 206-207. 
One report estimated that in the early 1960s the stray population crashed from 400,000 to 70,000 , though the animals seem to have rebounded as they became increasingly concentrated in Central Park. ${ }^{97}$ Cats also featured prominently in the lifestyle of single apartment-dwellers who enjoyed the city's unique pleasures but often found sustained human relationships fraught. The 1970s saw the emergence of a new discourse about pets wherein they were no longer just members of a household, but constituted the household itself, serving as 'the surrogate children - and husbands and wives - of Western society'. ${ }^{98}$ These years witnessed the emergence of a booming gourmet pet food market rooted in this heightened affect for pets. ${ }^{99}$ Animals had entered into the affective web of the family through the use of pets to impart on children lessons about care, love and duty. ${ }^{100}$ For some late moderns, pets had become their children.

The city's cats acquired this new symbolism in connection with the increased prominence granted to those who identified as 'child-free', a new social status among individuals of various sexual orientations. ${ }^{101}$ A 1975 magazine story entitled 'The only perfect relationship in this fickle world' profiled seemingly single New Yorkers (including an actress who insisted she was not a 'crazy cat lady'), praising their special bond with their cats as 'the most selfless love relationship we can have'. ${ }^{102}$ As the actress's pleading suggests, the image of these fashionably neurotic urban sophisticates was accompanied by the figure of the lonely, elderly female; a woman who risked muggings by venturing into Central Park after dark to feed the strays or required the assistance of the ASPCA to house herself and her wards. ${ }^{103}$ Such narratives maintained the animal's reputation for aloofness, but introduced new narratives about vulnerability and assertions about cats as fully fledged surrogates for companions.

\section{Intellectual orgasms versus impactful science}

The 'sadists play' slogan suggested it was not just beloved pets being abused but collective tax dollars. As demonstrator Barbara Nixon insisted, 'Some people may not care about animals, but it's our money. You can't feel detached when it's coming out of your pocket.' ${ }^{104}$ Taxes served the route through which the reader was to intervene in such state-supported sadism. The one-page 1977 Millennium Guild advertisement includes nine distinct invocations of 'your tax dollars', the 'misappropriation of

97 Montgomery, op. cit. (49). On the relocation to Central Park see John C. Devlin, 'Cats take over bird sanctuary', New York Times, 31 December 1963, p. 16.

98 'The great American animal farm', Time (23 December 1974) 104(26).

99 Steven Greenhouse, 'Dogs and cats - a \$2-billion market: pet food produces in gourmet race', New York Times, 27 January 1974, p. 135.

100 Grier, op. cit. (47), pp. 12-13.

101 See Elaine Tyler May, Barren in the Promised Land: Childless Americans and the Pursuit of Happiness, Cambridge, MA: Harvard University Press, 1995, pp. 181-210.

102 'The only perfect relationship in this fickle world', New York Magazine, 24 March 1975, pp. 49-55. The only couple depicted in the photo essay were the hosts of a pet care radio show.

103 'Cats in Central Park fare well', New York Times, 6 September 1976, p. 21; Lena Williams, 'ASPCA shelters 9 cats and helps destitute owner, 81, too', New York Times, 4 October 1977, p. 41.

104 Cited in Spira, op. cit. (8), pp. 206-207. 
funds', 'a greed for public funds'. ${ }^{105}$ The 'moral shock' designed to recruit participants invoked simultaneously the violence of the experiments and the exploitation of the reader's own money. ${ }^{106}$ Linking together morality and tax dollars has a venerable political lineage in the United States, dating back to Henry Thoreau's civil disobedience over his opposition to slavery, if not to the American Revolution itself. More specifically, sex research had long been a popular target among those who wanted to limit government spending on scientific research. ${ }^{107}$

Yet the evocation of squandered and abused federal dollars has greater historical specificity than might at first appear and became increasingly central to the evaluation of Aronson's work as the scientific community reflected on the ramifications of the protests outside the AMNH. In the rare cases when antivivisectionists had confronted Aronson in the past, they had withdrawn their individual membership from the museum. ${ }^{108}$ In contrast, Spira very much wanted to target Aronson's relationship with his government patron. Animal liberation, as a humanitarian movement, involved the withdrawal of government financial support in the form of research dollars geared towards experiments on captive animals, rather than increased government spending in this realm. Such rhetoric had real effects as the museum faced significant budgetary constraints due to municipal austerity measures. Its new president was particularly concerned with public relations in the hopes of securing new forms of corporate support for the museum as a cultural institution while also highlighting the importance of the culture industry to the New York economy. ${ }^{109}$

Soon criticism of wasted federal tax dollars would eclipse concerns about wasted animal life. This move occurred as taxation again became a contentious political issue against the backdrop of the post-1973 recession and the 'tax revolt'. The raising of taxes had not been an electoral question for several decades, but rather a policy pursued by both national parties. Initially the revolt was an ideologically polyvalent movement among homeowners until captured by supply-side economists within the Republican Party following California's 1978 Proposition 13.110 Historian Daniel Rodgers has analysed the 'thinning' of the metaphors Americans used to understand society since the 1970s as a wide range of anti-statist thinkers challenged the capacity of the welfare state to meet the needs of the citizenry. ${ }^{111}$ One of the most concrete forms this took was an opposition to how taxes supported 'wasteful' government

105 'Stop the cat-torture', op. cit. (93). See also 'Your money is paying for torture at the American Museum of Natural History', New York Times, 30 September 1976, p. 62.

106 On 'moral shocks' as recruitment tools see Jasper, op. cit. (82).

107 For example, the 1950s Reece Committee had targeted Alfred Kinsey. See Mark Solovey, Shaky Foundations: The Politics-Patronage-Social Science Nexus in Cold War America, New Brunswick, NJ: Rutgers University Press, 2013, p. 143.

108 See Edmund Smith to Aronson, 24 April 1952, DAB Papers, Box 3, Folder 8.

109 'American Museum pinched for funds', New York Times, 16 February 1976, p. 19. In 1975 the AMNH selected a new president based on his fundraising skills among private donors. See Geoffrey T. Hellman, 'You've simply got to go out and raise the scratch', New Yorker, 18 October 1976, pp. 45-69.

110 On the tax revolt as social movement see Isaac William Martin, The Permanent Tax Revolt: How the Property Tax Transformed American Politics, Stanford, CA: Stanford University Press, 2008.

111 Daniel Rodgers, The Age of Fracture, Cambridge, MA: The Belknap Press of Harvard University Press, 2011. 
programmes. Free-market conservatives refused to pay the costs of reconfigured social order. One effect of the tax revolt was a shift in the political economy of scientific research, one that posed a severe challenge to the pure-science ideal that Aronson had embraced for much of his career. ${ }^{112}$

The impact of the tax revolt on science manifested itself most clearly in the career of Wisconsin Senator and chair of the Appropriations Committee William Proxmire. In 1975, he instituted his highly publicized Golden Fleece Awards to castigate wasteful government spending. The very first award went to the National Science Foundation for the social-science grants it issued to study 'love' in human heterosexual relationships. Proxmire - who, as newspapers were fond of noting, was separated from his wife at the time - held that the wastefulness of such research was self-evident. He targeted sex research because "to explain even more about what we feel when we are "doing what comes naturally" constitutes an appalling disregard of any reasonable system of priorities'. ${ }^{113}$ In his formulation, the nature of sex was something obvious and unproblematic, the domain of private artistic and poetic expression rather than governmentsponsored science. Proxmire was a utilitarian. As he explained to one of the scientists skewered by his award, 'There is an endless unlimited variety of problems we could spend federal money exploring.' Such limitless possibilities for the pursuit of knowledge needed to be checked by the harsh calculus of financial prudence. 'I do not feel that this type of research should be done with taxpayers' dollars at a time when the average American taxpayer is struggling to keep his head above water.' ${ }^{114}$ In the immediate post-war era, the behavioural sciences sought patronage by emphasizing their potential for conducting basic research on human nature without the corrupting influence of immediate application. ${ }^{115}$ The recession demanded new priorities with utility at the forefront.

A few months after the first Golden Fleece Award, Psychology Today published an interview with Frank Beach. Proxmire's revolt against useless research percolated in the background as the interview considered the question of distributing care and resources across the species line. Beach strongly objected when asked whether he felt guilty about dedicating his time to studying the dog's sexed urination behaviour in a world of starving human children. He doubled down. He upheld an eroticized form of pure curiosity as the scientist's true path. Beach insisted that it was far nobler not to pursue immediate ends but rather to seek certain 'peak experiences' of true scientific breakthrough, a moment he knowingly called 'intellectual orgasm'. ${ }^{116}$ Beach defined the

112 See Tiago Mata and Tom Scheiding, 'National Science Foundation patronage of social science, 1970s and 1980s: congressional scrutiny, advocacy network, and the prestige of economics', Minerva (2012) 50, pp. 423-449.

113 William J. Eaton, 'Proxmire aims new punch at "love machine"' (1975), unknown source, Elaine Hatfield Papers, the Kinsey Institute for Research in Sex, Gender, and Reproduction, Inc., Bloomington, IN, Box 1, Series II, Folder 2.

114 William Proxmire to Elaine Walster [Hatfield], 3 April 1975, Elaine Hatfield Papers, Box 1, Series II, Folder 3.

115 Solovey, op. cit. (107).

116 Joyce Dudney Fleming and David Maxey, 'The drive of the pure researcher: pursuit of intellectual orgasm', Psychology Today (1975) 8(10), pp. 68-77. 
scientific life in terms of his freedom, autonomy and agency - the privilege of being beholden to no one. ${ }^{117}$ Beach and Aronson had worked together for eight years at the AMNH during the 1940s; decades later they remained close friends. Beach was also an important ally as Spira's claims that the cat experiments were mere mutilations unlikely to lead to new knowledge entered the pages of Science magazine.

In October 1976, reporter Nicholas Wade wrote about the 'public relations disaster' that was the museum's response to the animal rights protesters. Wade dismissed many of the concerns raised by the activists, namely that Aronson and his team derived sexual pleasure from torturing crippled animals. Writing for Science's readership, he stressed that the experiments reflected 'the standard physiological procedures of removing glands, nerves, or brain tissue'. Nevertheless, Aronson and the museum were not blameless targets of 'public passions'. ${ }^{118}$ Wade performed his own utilitarian calculus when he turned to the newly created Science Citation Index (SCI) for a 'second opinion' about the merits of Aronson's research. ${ }^{119}$ Wade found Aronson's programme wanting. Fourteen of the twenty-one articles from the cat project had never been cited between the creation of the SCI in 1965 and 1976. The seven remaining papers had an average citation rate of merely 5.6 per paper. ${ }^{120}$ Aronson and his allies objected to Wade's calculations, insisting that the behavioural sciences were dominated by rat researchers who tended not to cite research conducted on other species. ${ }^{121}$ The lack of citations also resulted from the care with which these scientists conducted their research. Psychologist Benjamin Sachs underscored how 'few scientists have contributed more to making us aware of the complex interactions between behavioral experience and the neurological and hormonal control of behavior'. Their work challenged neuroscience orthodoxy, knowledge typically 'derived from research less sophisticated than that characteristic of Aronson and Cooper'. ${ }^{122}$

Soon SCI's inventor, Eugene Garfield, entered the fray. He chastised Wade for his sloppy use of the index as the reporter had failed to properly delineate Aronson's field of study: it was incorrect to compare citations across different areas of biology where the number of workers and publications varied greatly. By the standards of his subfield, Aronson was reasonably well cited, leading Garfield to conclude that the research had some value. At his most generous, Garfield suggested that Aronson may be another Mendel: a great scientist whose research is not cited immediately and remains dormant but eventually comes to dominate a field. ${ }^{123}$

117 See Shapin, op. cit. (13).

118 Nicholas Wade, 'Animal rights: NIH cat sex study brings grief to New York Museum', Science (8 October 1976) 194, pp. 162-167, 162.

119 The published version of the SCI first appeared in 1969. See Eugene Garfield, 'The history and meaning of the journal impact factor', JAMA (2006) 295, pp. 90-93.

120 Wade, op. cit. (118), p. 164.

121 Beach to Science, 1 December 1976, in Eugene Garfield, 'Citation analysis and the anti-vivisection controversy: Part II. An assessment of Lester R. Aronson's citation record', Essays of an Information Scientist (2 November 1977) 3, pp. 316-325, 324-325.

122 Benjamin D. Sachs, 'Letter', Science (19 November 1976) 194, p. 786.

123 Eugene Garfield, 'Citation analysis of the anti-vivisection controversy', Essays of an Information Scientist (25 April 1977) 3, pp. 103-108, 104. 
Such generosity had its limits. Garfield was increasingly suspicious of generalized claims that we can never know in advance (and often not even in retrospect) what value "basic" research may have in the future'. His citation index was ultimately a technology of prediction, one useful for the future management of scarce scientific resources. ${ }^{124} \mathrm{He}$ suggested that the SCI could erode the long-standing justification of pure research. It was no longer sufficient for scientists to operate by the standards of their small and fairly isolated fields. Aronson could not simply complain that rat researchers failed to cite his work. He had certain obligations that made him responsible for the public-relations disaster. Garfield suggested that 'had Aronson done a bit of "selling" to his rat colleagues and perhaps helped to educate the public on the ramifications and value of his research, he might have prevented the unfortunate abuse heaped on him'. ${ }^{125}$ Scientists needed to be entrepreneurs, selling their knowledge to colleagues, patrons and the public. Like many of his contemporaries extending from the fields of economics to biology, Garfield offered a vision of how the regulation of human conduct need be governed by neither morality nor the legal system. The surest form of surveillance was not the opening of the laboratory to the public or to FOIA investigation, but rather the regular calculation of impact for the allocation of resources, whether money or animal lives. In this world, Aronson - not the animal rights activists - was the true outdated relic of a bygone era. ${ }^{126}$

\section{Conclusion}

The increased demand for utilitarian ends seems to have shaped Aronson and Cooper's final published report when it appeared in 1979. They placed the clinical applications of their research at the forefront, as never before. They introduced their experiments as a caution to neurologists who had long assumed that lesions of the amygdala or its malfunction caused hypersexuality. ${ }^{127}$ Alongside this new emphasis on utility was a renewed call for care. Their notion of care was not about animal welfare, but about the need for a careful attentiveness to experimental design, longitudinal studies and the full range of a species's unaltered behavioural repertoire. Echoing Sachs's letter to Science, they used citations to their AMNH colleagues to stress how this regime of care was rather unique to the tradition fostered in the Department of Animal Behavior. ${ }^{128}$

Organized opposition to animal experimentation dates back (at least) to the nineteenth century, but the great cat mutilation captures several significant shifts in this

124 Eugene Garfield, 'Is citation analysis a legitimate evaluation tool?', Scientometrics (1979) 1, pp. 359_ 375. See also Nicholas Wade, 'Citation analysis: a new tool for science administrators', Science (2 May $1975)$ 188, pp. 429-432.

125 Garfield, op. cit. (121), p. 323.

126 Michael Power, The Audit Society: Rituals of Verification, Oxford: Oxford University Press, 1999.

127 See Heinrich Klüver and Paul C. Bucy, 'Preliminary analysis of functions of the temporal lobes in monkeys', Archives of Neurology (1939) 42, pp. 979-1000.

128 Lester R. Aronson and Madeline L. Cooper, 'Amygdaloid hypersexuality in male cats re-examined', Physiology \& Behavior (1979) 22, pp. 257-265. 
history and is better understood through the lens of 1970 s political culture. Where the physiological laboratory of the Victorian gentleman of science was often his private refuge, Aronson's research required support from state funds and a consuming public. Occupying this para-public space enabled the forms of opposition that he faced. How his opponents debated the utility of Aronson's work reflected the ideological legacy of the 1960s in the form of a new rights consciousness that centred on transforming people's sensibilities about what constituted pain and for whom. Moreover, Spira deployed the FOIA, a progressive reform intended to combat governmental secrecy by augmenting the surveillance powers of individual citizens. Animal liberationists like Singer most readily identified with these social movements in their calls to recognize non-human agency in our formulations of the social contract. However, a very different ideological current came to shape the controversy's legacy: an anti-statist, neo-liberal economic discourse seemingly born out of the recession that continues, however, to govern the judgement of science's merit with greater intensity. Both ideological trends posed a challenge that eroded established norms for justifying scientific research projects in terms of the scientist's curiosity, autonomy and cultivated judgement. Both demanded new forms of accountability and surveillance. This episode illuminates how very different ideologies converged on the ideal of disinterested knowledge to produce a transformed utilitarian calculus for measuring the value of science. 